ENTITA : Jurnal Pendidikan Ilmu Pengetahuan Sosial dan Ilmu-Ilmu Sosial
http://ejournal.iainmadura.ac.id/index.php/entita
P-ISSN:2715-7555 E-ISSN:2716-1226

\title{
Peningkatkan Keterampilan Berpikir Kritis Siswa melalui Pembelajaran IPS Tipe Group Investigation pada Siswa Kelas VIII SMP IC Nurul Hidayah di Kabupaten Pasuruan
}

\author{
Sofiah Al Azizani \\ SMP IC Nurul Hidayah \\ sofiahalazizani92@gmail.com
}

\begin{abstract}
Critical thinking skills are the main provisions that students must have to face the current era of disruption. The central point that can be done to cultivate these skills is through education. This study aims to test the improvement of students' critical thinking skills through social studies learning Group Investigation type in VIII class contains of 20 students. This study used the Classroom Action Research method by Kemmis and McTaggart model. The research instrument in the form of observation sheets and tests were analyzed using a comparative descriptive approach. The results showed that Group Investigation type learning in social studies learning was proven to improve students' critical thinking skills, as evidenced by the following points; (1) The condition of pre-cycle students' critical thinking skills was $40 \%$ in a low condition, and 35\% were in the sufficient category; (2) In the first cycle the students' critical thinking skills below the minimum standard have been reduced to 25\%; (3) Then only $15 \%$ of students have critical thinking skills below the minimum standard. This study recommends testing other learning methods and models to improve students' critical thinking skills.
\end{abstract}

Keywords: Group Investigation, Critical Thinking Skills, Social Studies Learning

Abstrak

Keterampilan berpikir kritis menjadi bekal utama yang harus dimiliki siswa untuk menghadapi era disrupsi dewasa ini. Titik sentral yang dapat dilakukan untuk menumbuhkan keterampilan tersebut adalah melalui pendidikan. Penelitian ini bertujuan untuk menguji peningkatan keterampilan berpikir kritis siswa melalui pembelajaran IPS tipe Group Investigation pada siswa kelas VIII. Penelitian ini menggunakan metode Penelitian Tindakan Kelas model Kemmis dan McTaggart. Instrumen penelitian berupa lembar observasi dan tes yang dianalisis menggunakan pendekatan deskriptif komparatif. Hasil penelitian menunjukkan bahwa pembelajaran tipe Group Investigation dalam pembelajaran IPS terbukti dapat meningkatkan keterampilan berpikir kritis siswa, terbukti dari beberapa hal berikut; (1) Kondisi keterampilan berpikir kritis siswa pra-siklus sebesar $40 \%$ berada pada kondisi kurang, dan 35\% berada pada kategori cukup; (2) Pada siklus I keterampilan berpikir kritis siswa dibawah standar minimal telah berkurang menjadi 25\%; (3) Kemudian hanya tersisa $15 \%$ siswa yang memiliki keterampilan berpikir kritis dibawah standar minimal. Penelitian ini merekomendasikan agar menguji coba metode maupun model pembelajaran yang lain untuk meningkatkan keterampilan berpikir kritis siswa.

Kata Kunci: Group Investigation, Keterampilan Berpikir Kritis, Pembelajaran IPS

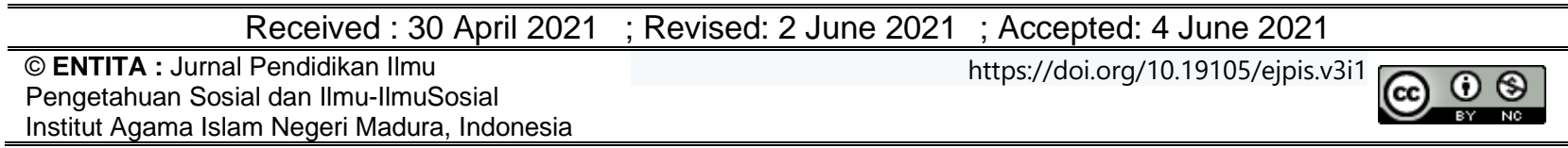




\section{Pendahuluan}

Globalisasi sebagai proses integrasi dunia secara nyata membawa dampak pada perubahan pandangan dunia, produk, pemikiran, dan aspek budaya lainnya serta menuntut setiap individu memiliki skill yang mumpuni (Sarmini \& Warsono, 2018). Pengaruh globalisasi pada setiap sektor dan tidak bisa lepas dari tantangan zaman agar mampu berpikir jernih dan rasional (Annavarapu, 2015). Lebih lanjut, globalisasi merupakan suatu proses sejarah panjang kehidupan yang menuntut setiap individu mampu beradaptasi dengan cepat dan kreatif (Roudometof, 2014). Globalisasi dewasa ini mengarahkan seluruh aspek kehidupan menjadi lebih modern dan serba canggih memberikan tantangan tersendiri pada dunia pendidikan agar memiliki peran lebih dalam menjamin kelangsungan hidup (Malihah, 2015).

Fakta bahwa pendidikan memegang peranan penting dalam proses peningkatan kualitas sumber daya manusia seyogyanya diarahkan untuk mewujudkan suasana belajar agar siswa aktif mengembangkan potensi dirinya untuk memiliki kekuatan spiritual, keagamaan, pengendalian diri, kepribadian, kecerdasan, akhlak, dan budi mulia, serta ketrampilan yang diperlukan dirinya, masyarakat, bangsa dan Negara (Hidayat \& Abin, 2012). Artinya perilaku yang tampak tidak dapat diukur dan diamati tanpa melibatkan proses mental seperti kesengajaan, keyakinan, motivasi dan sebagainya (Nurhadi, 2020).

Untuk memenuhi tuntutan pendidikan abad 21 ini, bangsa Indonesia harus mempersiapkan sumber daya manusia yang memiliki kompetensi dan keterampilan. Beberapa keterampilan yang dibutuhkan diantaranya yaitu keterampilan analitis (berfikir kritis), keterampilan interpersonal (komunikasi, kolaborasi dan tanggung jawab), kreatif dan inovatif, serta kemampuan literasi (Muhali, 2018). Salah satu keterampilan utama yang harus dimiliki untuk menghadapi era disruptif saat ini adalah berfikir kritis. Berfikir kritis merupakan suatu bentuk berfikir tingkat tinggi yang melibatkan semua proses berfikir yakni perolehan informasi, memahami, menganalisis, mengkorelasikan, menafsirkan, mengevaluasi, membuat penilaian, dan membuat penilaian tentang baik dan buruk atau benar dan salah (Safrida et al., 2018).

Berfikir kritis merupakan kemampuan kognitif untuk mengatakan sesuatu dengan penuh keyakinan karena bersandar pada alasan yang logis dan bukti empiris yang kuat (Yaumi \& Ibrahim, 2013). Berfikir kritis adalah proses berfikir sistematis dalam mencari kebenaran dan membangun keyakinan terhadap sesuatu yang dikaji dan ditelaah secara faktual dan realistis. Pengertian berfikir kritsi menurut Robert Ennis yaitu pemikiran reflektif 50 
yang masuk akal untuk memutuskan apa yang harus dipercaya atau dilakukan (Ennis, 1996). Jadi, penekanan Ennis adalah pada kewajaran, refleksi dan proses pengambilan keputusan.

Menurut Ennis, terdapat 12 indikator berfikir kritis yang dikelompokkan dalam 5 aspek keterampilan. Dari pembahasan berfikir kritis menurut Robert Ennis, dapat disimpulkan bahwa berfikri kritis adalah : (a) proses perfikir aktif untuk mengkaji hakikat dari suatu obyek, (b) memahami secara komprehensif tentang berbagai pendekatan agar muncul suatu keyakinan yang kuat, (c) membuat alasan rasional tentang obyek yang dikaji, (d) membuat asumsi-asumsi yang dikonstruksi berdasarkan pertimbangan dari berbagai alasan rasional, (e) mengungkap kandungan makna dengan merumuskan dalam bahasa yang sesuai dan bijaksana, (f) mengungkap bukti-bukti empiris dari setiap makna kata-kata yang telah dirumuskan, (g) membuat keputusan berdasarkan kajian mendalam dari bukti-bukti empiris yang ada, (h) mengevaluasi implikasi dari hasil keputusan yang dibuat (metakognisi).

Selain itu, berpikir kritis juga telah didefinisikan sebagai "berpikir yang memiliki maksud, masuk akal, dan berorientasi tujuan" dan "kecakapan untuk menganalisis sesuatu informasi dan ide-ide secara hati-hati dan logis dari berbagai macam perspektif" (Zubaidah, 2010). Secara umum nampak bahwa berpikir kritis yaitu proses intelektual yang aktif dan penuh dengan keterampilan dalam membuat pengertian atau konsep, mengaplikasikan, menganalisis, membuat sistesis, dan mengevaluasi. Semua kegiatan tersebut berdasarkan hasil observasi, pengalaman, pemikiran, pertimbangan, dan komunikasi, yang akan membimbing dalam menentukan sikap dan tindakan.

Keterampilan berpikir tidak dapat berkembang secara alamiah, sebab keterampilan berpikir harus diperkaya oleh berbagai stimulus lingkungan dan suasana yang beragam. Berpikir adalah suatu proses kognitif atau aktivitas mental untuk memperoleh pengetahuan (Renatovna, 2019). Berpikir juga bisa diartikan sebagai suatu keaktifan pribadi manusia yang mengakibatkan penemuan terarah sampai pada suatu tujuan (Wechsler et al., 2018). Dengan berpikir, seseorang akan mendapatkan suatu penemuan baru, setidaktidaknya orang menjadi tahu hubungan antar sesuatu.

Lebih jauh, berpikir kritis adalah proses mental untuk menganalisis atau mengevaluasi informasi. Informasi tersebut bisa didapatkan dari hasil pengamatan, pengalaman, akal sehat atau komunikasi (Dwyer et al., 2014). Individu yang menggunakan keterampilan berpikir kritis memikirkan hubungan antara variabel-variabel 
dengan mengembangkan pemahaman logis, memahami asumsi-asumsi dan bias-bias yang mendasari proses utamanya. Sehingga, kemampuan berpikir kritis yang dimiliki seseorang sangat membantu dalam mengambil keputusan karena berdasarkan pertimbangan yang matang dari berbagai aspek.

Berpikir kritis merupakan proses berpikir intelektual di mana pemikir dengan sengaja menilai kualitas pemikirannya, pemikir menggunakan pemikiran yang reflektif, independen, jernih, dan rasional. Selanjutnya, berpikir kritis adalah memberdayakan keterampilan atau strategi kognitif dalam menentukan tujuan (Hong et al., 2014). Proses tersebut dilalui setelah menentukan tujuan, mempertimbangkan, dan mengacu langsung kepada sasaran-merupakan bentuk berpikir yang perlu dikembangkan dalam rangka memecahkan masalah, merumuskan kesimpulan, mengumpulkan berbagai kemungkinan, dan membuat keputusan ketika menggunakan semua keterampilan tersebut secara efektif dalam konteks dan tipe yang tepat.

Berbagai kajian yang telah terbukti dapat menumbuhkan kemampuan berpikir kritis telah dilakukan. Praktik pemberian stimulus berupa umpan pertanyaan tingkat tinggi dalam proses pembelajaran di jenjang menengah dapat menumbuhkan respon perkembangan berpikir kritis, yang merupakan keterampilan berpikir tingkat tinggi (Nappi, 2017). Adopsi kurikulum model filosofis Reggio Emilia mengenai pemikiran kritis melalui pengajaran seni sejak dini terbukti dapat mendorong kemampuan berpikir kritis siswa (Fernández-Santín \& Feliu-Torruella, 2020). Selanjutnya, Pengintegrasian konteks lokal dengan materi pembelajaran di sekolah secara nyata memfasilitasi pengembangan pemikiran kritis siswa (Oh, 2017).

Pada kaitannya dengan pentingnya penguasaan keterampilan berpikir kritis pada dewasa ini, model pembelajaran kooperatif tipe Group Investigation dapat menjadi alternatif dalam menumbuhkan keterampilan tersebut. Mengingat tipe pembelajaran ini mengarahkan siswa untuk menemukan konsep maupun teori melalui proses sains berupa mengamati, mengelompokkan, menafsirkan, meneliti, dan kemudian mengomunikasikan (Akly et al., 2015). Pada sisi yang lebih detail, tipe pembelajaran ini menekankan siswa untuk berpikir dalam kelompok secara kritis, kreatif, dan analitis (Aini et al., 2018). Sehingga tipe pembelajaran ini sangat sesuai dengan indikator keterampilan berpikir kritis yang sama-sama berbasis pemikiran sains. Hal tersebut didukung dengan temuan bahwa tipe pembelajaran tersebut memiliki dampak positif dalam mencapai suatu tujuan penguasaan keterampilan tertentu (ŞiMŞEK, 2012). 
Secara nyata, pembelajaran IPS sebagai ilmu interdisiplin tersusun atas berbagai disiplin ilmu sosial membutuhkan keterampilan analisis kritis dalam mengkaji fenomena yang terjadi di masyarakat (Nurochim \& Ngaisah, 2020). Sehingga tidak dapat dipungkiri bahwa pembelajaran IPS menuntut siswa untuk memiliki keterampilan berpikir kritis agar lebih peka dalam mengkaji fenomena sosial. Tipe pembelajaran Group Investigation sebagai salah satu model pembelajaran kooperatif dipandang memiliki peran cukup sentral untuk menumbuhkan keterampilan berpikir kritis siswa dalam pembelajaran IPS.

Namun, berdasarkan data observasi awal, diketahui bahwa keterampilan berpikir kritis siswa masih rendah. Hal ini dapat dilihat dari rendahnya aktivitas siswa dalam mengajukan pertanyaan kepada guru ataupun merespon pertanyaan dari guru. Hasil tersebut senada dengan kajian yang menyatakan bahwa Kemampuan merumuskan pertanyaan merupakan salah satu indicator utama keterampilan berpikir kritis (Azizah et al., 2018). Sehingga, fenomena rendahnya keterampilan berpikir kritis siswa dalam Pembelajaran IPS menjadi problematika tersendiri yang dipandang penting untuk diberikan solusi melalui implementasi pembelajaran kooperatif tipe Group Investigation.

\section{Metode}

Penelitian ini merupakan penelitian tindakan kelas (Class Room Action Research) dengan pendekatan deskriptif komparatif menggunakan model Kemmis dan McTaggart yang meliputi empat alur (langkah): (1) perencanaan tindakan; (2) pelaksanaan tindakan; (3) observasi; dan (4) refleksi (Prihantoro \& Hidayat, 2019). Penelitian tindakan kelas ini dilakukan untuk mengetahui peningkatan keterampilan berpikir kritis siswa. Data diperoleh baik dari siswa Kelas VIII A IC Nurul Hidayah yang berjumlah 20 siswa maupun guru IPS sebagai sumber primer berdasarkan hasil tes maupun observasi selama pelaksanaan. Instrumen penelitian yang dipergunakan adalah lembar observasi dan tes yang disusun berdasarkan indikator variabel yang telah diuji dengan validitas isi dan reliabilitas instrumen. Berikut indikator keterampilan berpikir kritis yang digunakan dalam kajian ini;

Tabel 1. Indikator Keterampilan Berpikir Kritis

\begin{tabular}{|c|c|c|c|}
\hline $\begin{array}{l}\text { Keterampilan } \\
\text { Berfikir Kritis }\end{array}$ & Indikator & & Sub Indikator \\
\hline \multirow{4}{*}{$\begin{array}{l}\text { Memberikan } \\
\text { penjelasan } \\
\text { sederhana } \\
\text { (elementery } \\
\text { clarification) }\end{array}$} & Memfokuskan pertanyaan & ○ & $\begin{array}{l}\text { Mengidentifikasi atau merumuskan } \\
\text { pertanyaan } \\
\text { Mengidentifikasi atau merumuskan kriteria } \\
\text { untuk mempertimbangkan kemungkinan } \\
\text { jawaban }\end{array}$ \\
\hline & & ○ & Menjaga kondisi berpikir \\
\hline & Menganalisis argumentasi & ○ & Mengidentifikasi kesimpulan \\
\hline & & $\circ$ & Mengidentifikasi kalimat-kalimat pertanyaan \\
\hline
\end{tabular}




\section{Keterampilan Berfikir Kritis}

\section{Membangun keterampilan dasar (basicsupport)}

Menyimpulkan (inference)

\begin{abstract}
Membuat penjelasan lebih lanjut (advanced clarification)
\end{abstract}

Strategi dan taktik (stratgegies and tactics)

\section{Indikator}

Bertanya dan menjawab pertanyaan klarifikasi dan pertanyaan yang menantang

Mempertimbangkan kredibilitas (kriteria suatu sumber)

$$
\begin{aligned}
& \text { Mengobservasi dan } \\
& \text { mempertimbangkan hasil } \\
& \text { observasi }
\end{aligned}
$$

Membuat deduksi dan mempertimbngkan hasil deduksi

Membuat induksi dan mempertimbangkan induksi

Membuat dan mempertimbangkan kesimpulan

Mendefinisikan istilah, mempertimbangkan definisi

Mengidentifikasi asumsi

Memutuskan suatu tindakan

\section{Sub Indikator}

- Mengidentifikasi kalimat-kalimat bukan pertanyaan

- Mengidentifikasi dan menangani suatu ketidaktepatan

Melihat struktur dari suatu argumen

Membuat ringkasan

Memberikan penjelasan sederhana

Menyebutkan contoh

- Mempertimbangkan keahlian

Mempertimbangkan kemenarikan konflik

Mempertimbangkan kesesuaian sumber

Mempertimbangkan penggunaan prosedur yang tepat

Mempertimbangkan risiko untuk reputasi

Kemampuan untuk memberikan alasan

Melibatkan sedikit dugaan

- Menggunakan waktu yang singkat antara observasi dan laporan

Melaporkan hasil observasi

Merekam hasil observasi

Menggunakan bukti-bukti yang benar

Menggunakan akses yang baik

Menggunakan teknologi

Mempertanggungjawabkan hasil observasi

Siklus logika Euler

Mengkondisikan logika

Menyatakan tafsiran

Mengemukakan hal yang umum

Mengemukakan kesimpulan dan hipotesis

mengemukakan hipotesis

merancang eksperimen

menarik kesimpulan sesuai fakta

menarik kesimpulan dari hasil menyelidiki

Membuat dan menentukan hasil pertimbangan berdasarkan latar belakang fakta-fakta

- Membuat dan menentukan hasil pertimbangan berdasarkan akibat

- Membuat dan menentukan hasil pertimbangan berdasarkan penerapan fakta

- Membuat dan menentukan hasil pertimbangan

- Membuat bentuk definisi

- Strategi membuat definisi bertindak dengan memberikan penjelasan lanjut

- mengidentifikasi dan menangani ketidakbenaran yg disengaja

Membuat isi definisi

- Penjelasan bukan pernyataan

Mengonstruksi argumen

Mengungkap masalah

- Memilih kriteria untuk mempertimbangkan solusi yang mungkin

- Merumuskan solusi alternatif 
Peningkatkan Keterampilan Berpikir Kritis Siswa melalui Pembelajaran IPS Tipe Group Investigation pada Siswa Kelas VIII SMP IC Nurul Hidayah di Kabupaten Pasuruan

\begin{tabular}{|c|c|c|}
\hline $\begin{array}{l}\text { Keterampilan } \\
\text { Berfikir Kritis }\end{array}$ & Indikator & Sub Indikator \\
\hline & & ○ Menentukan tindakan sementara \\
\hline & & ○ Mengulang kembali \\
\hline & & - Mengamati penerapannya \\
\hline & & - Menggunakan argumen \\
\hline & Berinteraksi dengan orang & ○ Menggunakan strategi logika \\
\hline & lain & - Menggunakan strategi retorika \\
\hline & & - Menunjukkan posisi, orasi, atau tulisan \\
\hline
\end{tabular}

\section{Hasil dan Pembahasan}

\section{Keterampilan berpikir kritis Siswa}

Observasi awal menjadi hal penting yang harus dilakukan untuk mengetahui kondisi awal dan perrmasalahan dalam proses Pembelajaran IPS. Hal tersebut terlihat ketika guru menunjuk siswa untuk menyapiakan pertanyaan, hanya ada beberapa siswa yang sanggup bertanya. Siswa terlihat kurang memperhatikan penjelasan guru. Aktivitas pembelajaran didominasi oleh guru sehingga siswa terlihat pasif dalam pembelajaran. Kurangnya perhatian siswa terhadap materi pelajaran dalam proses pembelajaran menjadikan tingkat keterampilan berpikir kritis siswa masih kurang. Hasil observasi tersebut diperkuat dengan temuan data awal keterampilan berpikir kritis siswa yang termasuk kategori masih rendah. Data awal keterampilan berpikir kritis siswa secara lengkap dapat dilihat pada tabel berikut;

Tabel 2. Perbandingan Keterampilan berpikir kritis Siswa Pra Siklus, Siklus I, dan Siklus II Kelas VIII SMP IC Nurul Hidayah

\begin{tabular}{llclccccc}
\hline \multicolumn{1}{c}{ No. } & \multicolumn{2}{c}{ Kategori } & Rentang Nilai & \multicolumn{2}{c}{ Pra Siklus } & \multicolumn{2}{c}{ Siklus I } & \multicolumn{2}{c}{ Siklus II } \\
& & & $\mathbf{f}$ & $\%$ & $\mathbf{f}$ & $\%$ & $\mathbf{f}$ & $\%$ \\
1. & Sangat Baik (SB) & $3,51-4,00$ & 3 & 15 & 8 & 40 & 10 & 50 \\
2. & Baik (B) & $2,51-3,50$ & 2 & 10 & 7 & 35 & 7 & 35 \\
3. & Cukup (C) & $1,51-2,50$ & 7 & 35 & 5 & 25 & 3 & 15 \\
4. & Kurang (K) & $1,00-1,50$ & 8 & 40 & 0 & - & 0 & 0 \\
\hline
\end{tabular}

Data diatas merupakan hasil akumulasi keterampilan berpikir kritis siswa pada pra siklus siklus I, dan siklus II. Sebaran data hasil pra siklus menunjukkan bahwa keterampilan berpikir kritis siswa pada mata pelajaran IPS masih didominasi pada kategori Kurang (K) sebanyak 40\% siswa, Cukup (C) dengan jumlah 35\% siswa, kemudian berada pada kategori dan Baik (B) yaitu sebesar 10\%. Selain itu, hanya sebanyak 15\% siswa berada pada kategori Sangat Baik (SB). Siswa yang memenuhi ketuntasan atau memperoleh nilai di atas 2,50 hanya $25 \%$. Sebanyak $75 \%$ siswa masih berada pada kondisi belum memenuhi standar minimal. Maka dapat disimpulkan bahwa rata-rata keterampilan berpikir kritis siswa masih cukup rendah. 
Berdasarkan hal tersebut, perlu adanya peningkatan kualitas pembelajaran yang dapat meningkatkan keterampilan berpikir kritis siswa. Melalui pembelajaran Group Investigation (Gl) maka sistem pembelajaran akan lebih efektif karena pembelajaran ini tidak hanya mengacu pada guru, tapi lebih mengacu kepada siswa. Siswa juga dilatih untuk berpikir sains hingga berani menyampaikan hasil temuannya di depan kelas. Jadi, jika pembelajaran ini dilakukan akan menjadi sangat efektif karena guru tidak hanya terpacu untuk mengajarkan materi tercantum dalam buku paket saja, akan tetapi juga dapat mengembangkan materi sesuai dengan pemikiran kritis dari siswa dan mengajarkan cara berkomunikasi siswa di dalam kelas. Penerapan model pembelajaran Group Investigation (GI) diharapkan dapat meningkatkan keterampilan berpikir kritis siswa dalam Pembelajaran IPS.

\section{Deskripsi Siklus I}

Keberhasilan pelaksanaan tindakan pada Siklus I dapat dilihat dari adanya peningkatan keterampilan berpikir kritis siswa yang terlihat lebih baik dibandingkan dengan keterampilan berpikir kritis siswa pada saat sebelum tindakan (Tabel. 1). Hal ini dapat dilihat dari keterampilan berpikir kritis siswa pada pertemuan pertama, khususnya pada indikator kemampuan siswa mencari pernyataan yang jelas dari setiap pertanyaan, siswa berusaha mengetahui informasi dengan baik, siswa bersikap dan berpikir terbuka, dan siswa bersikap secara sistimatis dan teratur dengan bagian- bagian dari keseluruhan masalah. Berikut disajikan tabel persentase keterampilan berpikir kritis siswa pada Siklus I.

Hasil penilainan pada akhir siklus I menunjukkan bahwa keterampilan berpikir kritis siswa telah meningkat dibandingkan dengan pratindakan. Hal ini terlihat dari jumlah siswa yang memperoleh nilai keterampilan berpikir kritis kategori B (baik) meningkat menjadi sebesar $35 \%$. Selain itu pada kategori SB (Sangat Baik) mencapai $40 \%$. Akan tetapi pada kategori C masih $25 \%$ siswa. Siswa yang memenuhi ketuntasan baru mencapai $75 \%$. Berdasarkan nilai keterampilan berpikir kritis yang diperoleh dari lembar pengamatan dan hasil tes tersebut dapat dilihat bahwa keterampilan berpikir kritis siswa masih di bawah kriteria keberhasilan yang diharapkan. Untuk itu perlu ada perbaikan tindakan pada siklus II.

\section{Deskripsi Siklus II}


Data pada Tabel. 1 tersebut menunjukkan bahwa keterampilan berpikir kritis siswa mengalami peningkatan. Sebagian siswa memperoleh nilai keterampilan berpikir kritis dengan kategori B (Baik) yaitu sebanyak 7 siswa atau 35\% dari keseluruhan siswa. Sedangkan sebanyak 10 siswa atau 50\% siswa memperoleh nilai keterampilan berpikir kritis dengan kategori SB (Sangat Baik). Hanya 3 siswa atau 15\% siswa yang memiliki nilai keterampilan berpikir kritis kategori C (Cukup). Dengan kata lain, sebanyak $85 \%$ siswa sudah memperoleh nilai keterampilan berpikir kritis tuntas yaitu berada pada kategori nilai B (Baik) dan SB (Sangat Baik). Berdasarkan hal tersebut maka dapat disimpulkan bahwa keterampilan berpikir kritis siswa sudah sesuai dengan kriteria keberhasilan yang diharapkan.

\section{Peningkatkan Keterampilan berpikir kritis Siswa Melalui Pembelajaran IPS Tipe Group Investigation}

Berdasarkan hasil penelitian yang dilakukan pada saat Siklus I dan Siklus II, dapat diketahui adanya peningkatan keterampilan berpikir kritis yang cukup signifikan sesuai dengan perbandungan pada grafik berikut;

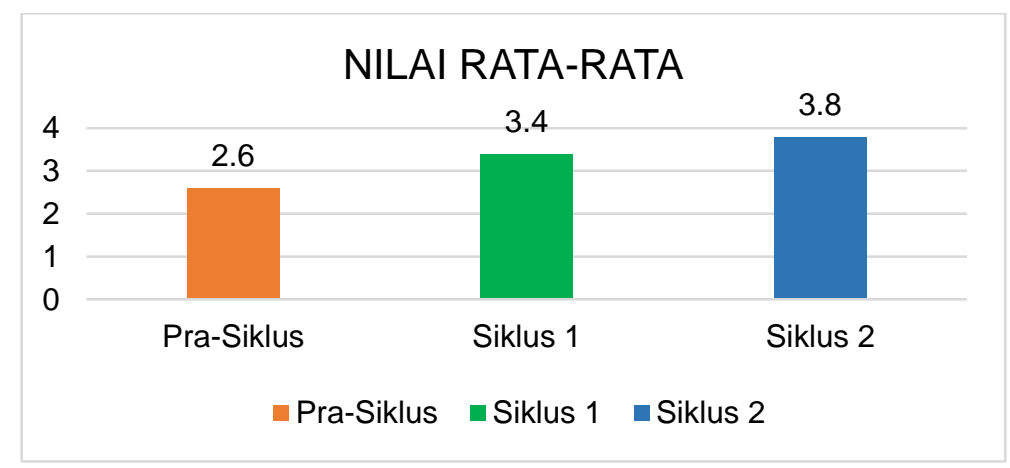

Gambar 1. Grafik Peningkatan Nilai Rata-Rata pada Siklus I dan Siklus II

Berdasarkan gambar tersebut, dapat dilihat pada kondisi awal nilai rata- rata siswa sebesar 2,6; meningkat pada Siklus I menjadi 3,4 dengan kategori Baik (B); dan meningkat lagi pada Siklus II menjadi 3,8 dengan kategori sangat baik. Nilai ketuntasan pada siklus I dan siklus II dapat dilihat pada gambar di bawah ini: 


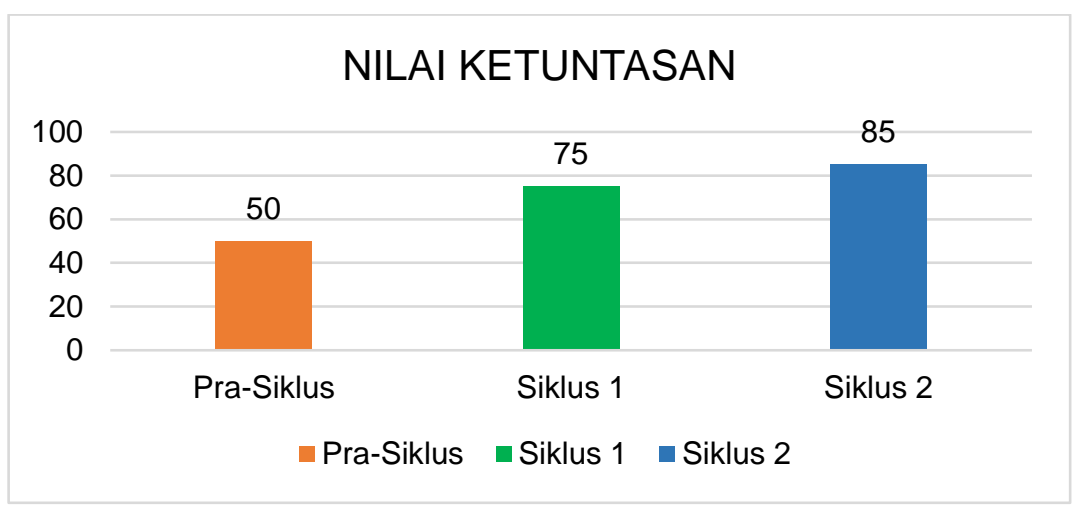

Gambar 2. Persentase Ketuntasan Nilai Berpikir Kritis

Pada kondisi awal hanya sebanyak 50\% siswa yang memperoleh nilai ketuntasan, pembelajaran Group Investigation dapat meningkatkan kemampuan berpikir kritis dalam Pembelajaran IPS siswa kelas VIII SMP IC Nurul Hidayah. Terbukti dengan meningkatnya nilai ketuntasan pada siklus 1 sebesar $75 \%$, kemudian pada siklus kedua menjadi $85 \%$.

Ditinjau dari keterlaksanaan pembelajaran, Guru memberikan masalah yang harus didiskusikan atau didialogkan secara mendalam oleh kelompok tersebut. Setelah dibentuk kelompok, kemudian guru mencoba melemparkan pertanyaan kepada setiap kelompok secara acak. Hal ini agar siswa dilatih memberikan pengalaman melalui proses usaha menemukan informasi, konsep atau pengertian yang diperlukan dengan mengoptimalkan dialog dan berpikir kritis antar sesama. Setelah berdiskusi dalam kelompok kecil (2 orang), kemudian membentuk kelompok besar yang beranggotakan 4-5 orang secara acak. Anggota kelompok kecil tersebut kemudian akan bertukar kelompok dan membentuk kelompok besar yang beranggotakan 4-5 siswa secara acak. Dalam kelompok besar tersebut, siswa berdialog secara lebih dalam dan berpikir kritis dengan bertukar informasi yang diketahuinya. Setelah selesai berdiskusi, kemudian guru memberikan kesempatan kepada siswa untuk mempresentasikan hasil diskusinya.

Guru menunjuk satu siswa yang ada dalam kelompok serta satu siswa dalam kelompok lain secara acak untuk memberikan dan mengutarakan mengenai informasi tentang materi yang telah didiskusikan dalam kelompoknya. Setelah siswa melakukan presentasi, guru memberikan materi kepada siswa. Guru memberikan refleksi mengenai proses pembelajaran yang telah dilakukan. Guru juga memberikan kesimpulan dari materi yang telah dibahas bersama.

Kekurangan guru saat melaksanakan kegiatan pembelajaran dengan model GI pada siklus I adalah guru kurang bisa mengatur pembagian waktu yang sesuai dengan 58 
Peningkatkan Keterampilan Berpikir Kritis Siswa melalui Pembelajaran IPS Tipe Group Investigation pada Siswa Kelas VIII SMP IC Nurul Hidayah di Kabupaten Pasuruan

rencana pelaksanaan pembelajaran. Akan tetapi pada siklus II, guru sudah bisa mengatur waktu di setiap langkah pembelajaran dengan lebih tepat.

\section{Peningkatan keterampilan berpikir kritis siswa melalui Metode pembelajaran Group Investigation}

Penerapan Metode pembelajaran Group Investigation dapat meningkatkan keterampilan berpikir kritis dalam Pembelajaran IPS siswa kelas VIII SMP IC Nurul Hidayah. Hal ini dapat dilihat dari adanya peningkatan jumlah siswa yang memperoleh nilai keterampilan berpikir kritis memenuhi ketuntasan. Keterampilan berpikir kritis pada penelitian ini mengacu pada indikator keterampilan berpikir kritis menurut Ennis (Saputra, 2020), yang meliputi kemampuan siswa mencari pernyataan yang jelas dari setiap pertanyaan, kemampuan siswa mencari alasan, siswa berusaha mengetahui informasi dengan baik, siswa memakai sumber yang memiliki kredibilitas dan menyebutkannya, siswa memperhatikan situasi dan kondisi secara keseluruhan, siswa berusaha tetap relevan dengan ide utama, siswa mengingat kepentingan yang asli dan mendasar, siswa mencari alternatif, siswa bersikap dan berpikir terbuka, siswa mengambil posisi ketika ada bukti yang cukup untuk melakukan sesuatu, siswa mencari penjelasan sebanyak mungkin apabila memungkinkan, dan siswa bersikap secara sistimatis dan teratur dengan bagianbagian dari keseluruhan masalah.

Metode pembelajaran Group Investigation dapat meningkatkan kemampuan siswa mencari pernyataan yang jelas dari setiap pertanyaan. Hal ini dapat dilihat dari partisipasi siswa dalam kelompoknya. Hal ini disebabkan karena deep dialogue (dialog mendalam) merupakan percakapan yang bertujuan untuk mengeluarkan ide, informasi, ataupun pengalaman, sehingga menjadikan siswa berpartisipasi dalam kegiatan kelompoknya (Salamah, 2018). Ide, informasi, ataupun pengalaman yang diugkapkan siswa dalam kelompoknya menjadikan siswa berusaha untuk mencari pernyataan yang jelas dari setiap pertanyaan.

Metode pembelajaran Group Investigation dapat meningkatkan kemampuan siswa mencari alasan. Hal ini dapat dilihat dari pengaruh interaksi keaktifan yang lain membuat siswa mau menjawab pertanyaan yang diberikan kelompok lain ataupun memberikan tanggapan kepada kelompok lain. Hal ini disebabkan karena peran masing-masing individual dalam Grup saling berpengaruh dalam menganalisis, membuat pertimbangan, dan mengambil keputusan secara tepat dan benar dalam menanggapi pertanyaan yang 
diberikan oleh guru ataupun oleh kelompok lain. Sesuai dengan kenyataan bahwa pengetahuan dan perkembangan kognitif individu berasal dari sumber-sumber sosiokultural yang ada di sekitar dirinya (El Rizaq \& Sarmini, 2020).

Metode pembelajaran Group Investigation dapat meningkatkan kemampuan siswa berusaha mengetahui informasi dengan baik. Hal ini dapat dilihat dari kegiatan siswa menggunakan buku dan sumber lain dalam melakukan diskusi. Hal ini disebabkan karena dalam tahapan kegiatan pembelajaran Group Investigation, siswa diberikan tugas untuk didiskusikan dengan kelompoknya (Wahyuni, 2016), sehingga untuk mengerjakan soalsoal tersebut siswa menggunakan buku ataupun sumber referensi lain yang sesuai.

Metode pembelajaran Group Investigation dapat meningkatkan kemampuan siswa memakai sumber yang memiliki kredibilitas dan menyebutkannya. Hal ini dapat dilihat dari jawaban soal tes mengenai pengertian kebutuhan dan pengertian alat pemuas kebutuhan. Meningkatnya kemampuan siswa memakai sumber yang memiliki kredibilitas dan menyebutkannya disebabkan karena untuk mendefinisikan pengertian dari kebutuhan dan alat pemuas kebutuhan, siswa harus menggunakan sumber referensi dan menyebutkanyya.

Metode pembelajaran Group Investigation dapat meningkatkan kemampuan siswa memperhatikan situasi dan kondisi secara keseluruhan. Hal ini dapat dilihat dari kegiatan siswa memperhatikan guru dan siswa lain yang sedang mengajukan pertanyaan ataupun menjawab pertanyaan. Hal ini disebabkan karena langkah-langkah Metode pembelajaran Group Investigation memberikan kesempatan kepada siswa untuk bertanya dan menjawab pertanyaan, sehingga siswa harus memperhatikan ketika guru ataupun siswa sedang bertanya dan menjawab pertanyaan agar siswa mampu memahami materi yang diajarkan (Tan et al., 2007). Berbagai uraian analisis tersebut menunjukkan bahwa penerapan Metode pembelajaran Group Investigation dapat meningkatkan keterampilan berpikir kritis siswa siswa kelas VIII SMP IC Nurul Hidayah pada Pembelajaran IPS.

\section{Kesimpulan}

Kondisi keterampilan berpikir kritis siswa pra-siklus sebesar $40 \%$ berada pada kondisi kurang, dan 35\% berada pada kategori cukup. Pada siklus I keterampilan berpikir kritis siswa dengan kondisi cukup telah berkurang menjadi 25\%. Kemudian pada siklus II kondisi siswa memiliki keterampilan berpikir kritis pada kategori cukup berkurang lagi menjadi 15\%. Persentase jumlah siswa yang memperoleh nilai ketuntasan keterampilan berpikir kritis pada kondisi awal hanya sebanyak $25 \%$ siswa. Pembelajaran Group 
Peningkatkan Keterampilan Berpikir Kritis Siswa melalui Pembelajaran IPS Tipe Group Investigation pada Siswa Kelas VIII SMP IC Nurul Hidayah di Kabupaten Pasuruan

Investigation dapat meningkatkan keterampilan berpikir kritis dalam Pembelajaran IPS siswa kelas VIII SMP IC Nurul Hidayah. Terbukti dengan meningkatnya nilai ketuntasan pada siklus 1 sebesar $75 \%$, kemudian pada siklus kedua menjadi $85 \%$, yaitu lebih besar dari $60 \%$ dari kondisi awal sebelum diberikan treatmen tipe pembelajaran Group Investigation. Hal ini menunjukkan bahwa model pembelajaran Group Investigation dalam pembelajaran IPS dapat meningkatkan keterampilan berpikir kritis siswa dengan amat baik.

\section{Referensi}

Aini, Z., Ramdani, A., \& Raksun, A. (2018). A Mastery Of Biological Concept And Critical Thinking Ability Differences Of Grade Ten Student Of Man 1 Praya On The Implementation Of Cooperative-Based Learning Group Investigation Type And Guided Inquiry-Based Learning. J. Pijar MIPA, 1(1), 19-23. https://doi.org/10.29303/jpm.v13i1.466

Akly, N., Jurusan, A. H., Fisika, P., Tarbiyah, F., \& Keguruan, D. (2015). Efektivitas Penerapan Model Pembelajaran Kooperatif Tipe Group Investigation (Gl) Terhadap Hasil Belajar Fisika. Jurnal Pendidikan Fisika, 3(1), 52-57. http:/journal.uinalauddin.ac.id/indeks.php/PendidikanFisika

Annavarapu, S. (2015). Religious Nationalism in a Global Age: The Case of Hindu Nationalism. Journal of Developing Societies, 31(1), 125-146. https://doi.org/10.1177/0169796X14562943

Azizah, M., Sulianto, J., Cintang, N., Pendidikan Guru, J., \& Dasar, S. (2018). Analisis Keterampilan Berpikir Kritis Siswa Sekolah Dasar pada Pembelajaran Matematika Kurikulum 2013. Jurnal Penelitian Pendidikan, 35(1), 61-70. https://doi.org/10.15294/jpp.v35i1.13529

Dwyer, C. P., Hogan, M. J., \& Stewart, I. (2014). An integrated critical thinking framework for the 21st century. Thinking Skills and Creativity, 12, 43-52. https://doi.org/10.1016/j.tsc.2013.12.004

El Rizaq, A. D. B., \& Sarmini. (2020). Integrasi nilai karakter lokal dalam pengembangan bahan ajar IPS untuk meningkatkan wawasan kebangsaan siswa. Jurnal Teori Dan Praksis Pembelajaran IPS, 5(1), 19-27. https://doi.org/10.17977/um022v5i12020p019 Ennis, R. H. (1996). Critical thinking. Prentice-Hall.

Fernández-Santín, M., \& Feliu-Torruella, M. (2020). Developing critical thinking in early childhood through the philosophy of Reggio Emilia. Thinking Skills and Creativity, 37, 
100686. https://doi.org/10.1016/j.tsc.2020.100686

Hidayat, A., \& Abin, S. (2012). Pengelolaan Pendidikan; Konsep, Prinsip dan Aplikasi dalam Mengelola Sekolah dan Madrasah. Kaukaba.

Hong, J. C., Hwang, M. Y., Liao, S., Lin, C. S., Pan, Y. C., \& Chen, Y. L. (2014). Scientific reasoning correlated to altruistic traits in an inquiry learning platform: Autistic vs. realistic reasoning in science problem-solving practice. Thinking Skills and Creativity, 12, 26-36. https://doi.org/10.1016/j.tsc.2013.12.002

Malihah, E. (2015). An ideal Indonesian in an increasingly competitive world: Personal character and values required to realise a projected 2045 'Golden Indonesia.' Citizenship, Social and Economics Education, 14(2), 148-156. https://doi.org/10.1177/2047173415597143

Muhali. (2018). Seminar Nasional Lembaga Penelitian dan Pendidikan (LPP) Mandala. Prosiding Seminar Nasional Lembaga Penelitian Dan Pendidikan (LPP) Mandala, $O(0)$. http://ejournal.mandalanursa.org/index.php/Prosiding/article/view/425

Nappi, J. S. (2017). The Importance of Questioning in Developing Critical Thinking Skills. Delta Kappa Gamma Bulletin, 84(1), 30.

Nurhadi. (2020). Transformasi Teori Kognitivisme Dalam Belajar Dan Pembelajaran. In Jurnal Pendidikan dan Sains (Vol. 2, Issue 1). https://doi.org/10.36088/BINTANG.V2I1.540

Nurochim, \& Ngaisah, S. (2020). Ilmu Sosial dan Kemampuan Berpikir Kritis Matematis. ENTITA: Jurnal Pendidikan IImu Pengetahuan Sosial Dan IImu-IImu Sosial, 2(1), 51. https://doi.org/10.19105/ejpis.v1i2.3306

Oh, K.-A. (2017). Developing Critical Thinking Skills Through a Mandatory English Course in Korean Higher Education. English Teaching, 72(4), 53-80. https://doi.org/10.15858/engtea.72.4.201712.53

Prihantoro, A., \& Hidayat, F. (2019). Melakukan Penelitian Tindakan Kelas. Ulumuddin : Jurnal IImu-IImu Keislaman, 9(1), 49-60. https://doi.org/10.47200/ulumuddin.v9i1.283

Renatovna, A. G. (2019). Modern Approaches to the Development of Marine Antifouling Coatings. Inorganic Materials: Applied Research, 10(6), 1384-1389. https://doi.org/10.1134/S2075113319060029

Roudometof, V. (2014). Nationalism, globalization and glocalization. Thesis Eleven, 122(1), 18-33. https://doi.org/10.1177/0725513614535700

Safrida, L. N., Ambarwati, R., Adawiyah, R., Ermita, D., \& Albirri, R. (2018). Analisis Kemampuan Berpikir Kritis Mahasiswa Program Studi Pendidikan Matematika. In 
Peningkatkan Keterampilan Berpikir Kritis Siswa melalui Pembelajaran IPS Tipe Group Investigation pada Siswa Kelas VIII SMP IC Nurul Hidayah di Kabupaten Pasuruan

EDU-MAT Jurnal Pendidikan Matematika (Vol. 10, Issue 1). https://ppjp.ulm.ac.id/journal/index.php/edumat/article/view/5095

Salamah, U. (2018). Pembelajaran Menulis Karya IImiah Berbasis Deep Dialogue CriticalCreative Thinking (DDCCT). JINoP (Jurnal Inovasi Pembelajaran), 4(1), 90. https://doi.org/10.22219/jinop.v4i1.5718

Saputra, H. (2020). Kemampuan Berfikir Kritis Matematis. Perpustakaan IAI Agus Salim, 2(April), 1-7.

Sarmini, \& Warsono. (2018). The role of education in the culture of four pillar poverty to establish the nationalism of young generation The role of education in the culture of four pillar poverty to establish the nationalism of young generation. Journal of Physics: Conference Series, 953.

ŞIMŞEK, U. (2012). The effects of reading-writing-presentation and group investigation methods on students' academic achievements in citizenship lessons. Eğitim Bilimleri Araştırmaları Dergisi, 2(2), 189-201.

Tan, I. G. C., Lee, C. K. E., \& Sharan, S. (2007). Group investigation effects on achievement, motivation, and perceptions of students in Singapore. Journal of Educational Research, 100(3), 142-154. https://doi.org/10.3200/JOER.100.3.142-154

Wahyuni, R. (2016). Pembelajaran Kooperatif Bukan Pembelajaran Kelompok Konvensional. Jurnal Pendidikan Dasar (JUPENDAS), 3(1). http://jfkip.umuslim.ac.id/index.php/jupendas/article/view/136

Wechsler, S. M., Saiz, C., Rivas, S. F., Vendramini, C. M. M., Almeida, L. S., Mundim, M. C., \& Franco, A. (2018). Creative and critical thinking: Independent or overlapping components? Thinking Skills and Creativity, 27, 114-122. https://doi.org/10.1016/j.tsc.2017.12.003

Yaumi, \& Ibrahim. (2013). Pembelajaran Berbasis Kecerdasan Jamak. Prenadamedia Group.

Zubaidah, S. (2010). Berfikir Kritis: Kemampuan Berpikir Tingkat Tinggi Yang dapat Dikembangkan Melalui Pembelajaran Sains. Seminar Nasional Sains 2010 Dengan Tema "Optimalisasi Sains Untuk Memberdayakan Manusia," January 2010, 11. 
Sofiah Al Azizani

ENTITA Vol. 3 No. 1, June 2021 